\title{
Effects of Forest Fire on the Regeneration Potentials of Tree Species in Olokemeji Forest Reserve, Ogun State, Nigeria
}

\section{"OLOKETUYI, AJ; ADEOYE, OT; AINA-ODUNTAN, OA; ODIAKA, IE; AFOLABI, OS}

Forestry Research Institute of Nigeria, PMB.5054, Jericho. Ibadan. Nigeria

*Corresponding Author Email: akinoloketuyi@gmail.com, Tel: +2347032569441

\begin{abstract}
Effects of forest fire on the regeneration potential of trees at Olokemeji Forest Reserve was established in this study. The Olokemeji fire experimental plot was selected at the reserve. The site was divided into three plots; late fire treatment was applied to Plot A, Early fire treatment was also applied to Plot B and no fire treatment at plot C (Control plot). The diameter at breast height $(\mathrm{dbh})$ and tree height $(\mathrm{m})$ of the tree species in the plots were assessed prior and post fire treatment. The regeneration potential of the selected plots after burning were assessed through the occurrence of saplings and seedlings obtained. The highest basal area $\left(\mathrm{m}^{2}\right)$ were found in plot C followed by plot B and Plot C with mean value of $0.64,0.55$ and $0.30 \mathrm{~m}^{2}$ respectively. The number of stems per plot ranged from 25 to 67 . The regeneration potentials of the three plots were found to be noteworthy. Early and late year fire regime adopted had both positive and negative effect on the regeneration potentials of tree species. This study has established the effect and relevance of fire on forest and wildlife management. It's therefore recommended in this study that Prescribed or controlled burning should be encouraged as appropriate sivilcultural management tool for stimulating basal area growth, natural regeneration, production of tree species seedlings and saplings.
\end{abstract}

\section{DOI: https://dx.doi.org/10.4314/jasem.v25i6.5}

Copyright: Copyright $(0) 2021$ Oloketuyi et al. This is an open access article distributed under the Creative Commons Attribution License (CCL), which permits unrestricted use, distribution, and reproduction in any medium, provided the original work is properly cited.

Dates: Received: 20 March 2021; Revised: 27 April 2021; Accepted: 07 May 2021

Keywords: Forest fire, fire triangle, treatment, regeneration potential, and tree response.

Forest fire is defined as uncontained and freely spreading combustion which consumes the natural fuels of a forest. Duffy, litter, grass, dead branch of woods, snags, logs, stumps, weed, brush, foliage and to a limited degree, green trees (Oloketuyi, 2020). Forest fire can be described, depending on the part of the forest in which it occurs (from the mineral soil, to the tree tops) as ground, surface and crown fires or a combination of any of these. Fire occurs in the forest when there is a sufficient quality of dried fuel, in a combustible state. Fire is a combination of fuel; heat and oxygen which forms the fire triangle. The absence of any of the fire components of heat and fuel means the absence of fire. No two forest fires are the same, as great differences exist in the character of the available inflammable materials. Since materials have distinctive burning characteristics, there tend to be differences in forest fire behaviours (Adegbola, 1983). It's pertinent to review the ecology of natural regeneration in seasonally dry tropical forests (SDTFs). SDTFs, which originally represented $42 \%$ of the tropical vegetation worldwide (Murphy and Lugo, 1995), are the most threatened tropical terrestrial ecosystem, due to the conversion of these areas into agricultural land (Sanchez-Azofeifa et al., 2005).
Thus, scientific knowledge, specifically regarding regeneration pathways, is crucial to the restoration of these forests. SDTFs have particular natural regeneration attributes that need to be clarified. Although these regeneration characteristics can be limiting in certain situations, they can also be used to assist in the recovery of these forests. If these characteristics are not well understood, we risk using inappropriate strategies based on studies from moister tropical forests, where most of the studies on forest recovery are being developed (Meli, 2003). For instance, tree fall gaps, which are focal regeneration sites in moister tropical forests, can decrease the seedling survival in SDTFs even for light-demanding trees because of the extreme temperatures and low humidity. Re sprouting after injury, on the other hand, is a widespread occurrence in SDTFs. Several aspects of the ecology of SDTFs have been reviewed previously. A comprehensive review of SDTFs can be found in the book Seasonally Dry Tropical Forests; distribution patterns and ecological characteristics are discussed by Murphy and Lugo (1986); and seed and seedling ecology in SDTF species are extensively reviewed. It is needful to fully appreciate the importance of fire in the forest, so as to acknowledge 
the economic basis for fire control, prescription and management in forests, thereby presenting its necessity as a pre-requisite for the profitable use of land. Udugba (1997). Tree dynamics can be determined by climates, soil factors and special animal relations. In the dry tropics, however, fire is a major determinant, which influences the rate and pattern of growth and the quality of final trees. Any tree can be killed, depending on the duration and intensity of the fire. A prolonged and high intensity fire destroys all available vegetation, leaving no chance for comparison of resistibility or susceptibility of individual tree species. Oloketuyi, et al., (2020) observed that the increase in the internal temperature of living cells to a lethal level during fires, kills the phloem and the cambial tissues, making it almost impossible for the xylem tissues to function. Cambial deaths caused by fire has been found to affect the growth pattern of trees (Luke et al., 1978). Fire damage to trees occurs, when there are enough combustible ground litter or suspended materials to sustain a fire and the radiated heat, generated from fire outside the stand are maintained long enough to damage the growth. Also, fire within the stand scorches leaves damages conductive tissues beneath the bark and results in defoliation and possible deaths
(Simpfendofer, 1989). Usually, after fires of considerable damage, different forest types/vegetation replaces the old stand, having a profound effect on the existing wildlife habitat; biomass productivity; and landscape susceptibility to future disturbances such as floods and erosion. Mortality and reduction in number of biodiversity is an immediate and obvious effect of fire, within an ecosystem.

\section{MATERIALS AND METHODS}

The Study Sites: Olokemeji Forest Reserve (F.R.), is located on latitude $70^{\circ} 25^{\prime}$ North and longitude $3^{\circ} 32^{\prime}$ East The study site lies within this forest reserve approximately $32 \mathrm{~km}$ west of Ibadan city and $35 \mathrm{~km}$. The fire investigation plot was set up in 1929 by the colonial masters. In Aubreville's (1949) classification, Olokemeji falls within the region of Sous-climate baculeen-dahomeen, a subdivision of the Climate Guinea-forest, with less than $30 \mathrm{~mm}$ rainfall. Its lies on the transition between the Lowland Rain Forest and Derived Savannah zones (Oloketuyi, 2020). Moist forest of several types covers the remainder of the reserve, except for areas of plantations. The reserve is lying between altitudes $90 \mathrm{~m}$ and $140 \mathrm{~m}$ above sea level (a.s.1.).

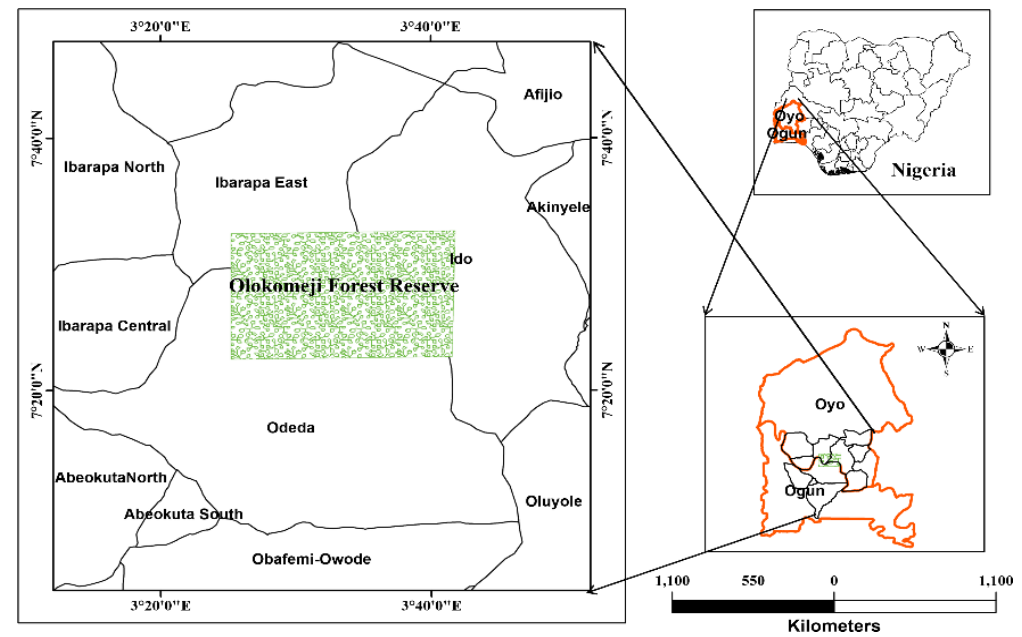

Fig 1: The Study Area. (Source: Oloketuyi, 2020.)

Data Collection Method: Sample Plot Location: The Investigation 254 at Olokemeji, was divided into three parts Plot A late burning, Plot B early burning and Plot C Control. Each Plot measuring 0.42 acre $(0.1735 \mathrm{Ha}$.). The plots were separated from one another by fire traces/fire ride.

Burning of the Plots: Plot A was set on fire at the peak of the dry season 12th March, 2019. While Plot B was set on fire at the initial stage of the dry season on the 22rd November, 2018. Measurement of individual trees at the investigation plot was carried out before and after the fire treatment of Plot A and Plot B, each tree (10 cm girth and above) were measured for girth at breast height, with a girthing tape.

Data Analysis: Basal Area Calculation: The basal area of all trees in the sample plots was calculated using the formula:

$$
B A=\frac{\pi D^{2}}{4}
$$


Where $\mathrm{BA}=$ Basal area $\left(\mathrm{m}^{2}\right), \mathrm{D}=$ Diameter at breast

height $(\mathrm{cm})$ and $\pi \mathrm{T}=$ Pie $(3.142)$.

Regeneration status: The status of regeneration of species was determined 6 months after burning based on population size of seedlings and saplings as reported by (Khan et al. 1987, Shankar 2001, Khumbongmayum et al. 2006).Using this methods allow visual recording of seedlings and saplings through counting and botanical identification of individual species encountered in plots A and B.

\section{RESULTS AND DISCUSSION}

The result of the tree height $(\mathrm{m})$ (Table 1) showed that the highest tree height was in plot $\mathrm{C}$ followed by plot $A$ and plot B with mean value of $15.25,10.95$ and $8.95 \mathrm{~m}$ respectively. The highest basal area $\left(\mathrm{m}^{2}\right)$ (Table 3 ) were found in plot C followed by plot A and Plot B with mean value of $0.64,0.55$ and $0.30 \mathrm{~m}^{2}$ respectively. The number of stems per plot ranged from 25 to 67.

Table 1. Descriptive statistics for Tree height $(\mathrm{m})$ in the study area

\begin{tabular}{llll}
\hline HEIGHT $(\boldsymbol{m})$ & PLOT A & PLOT B & PLOT C \\
\hline Mean & 10.95625 & 8.954545455 & 15.25373134 \\
Standard Error & 0.666220344 & 0.402490715 & 0.835067382 \\
Median & 11.8 & 8 & 14 \\
Mode & 7 & 6 & 15 \\
Standard Deviation & 3.768711382 & 2.984951031 & 6.835321108 \\
Sample Variance & 14.20318548 & 8.90993266 & 46.72161465 \\
Kurtosis & -1.673486699 & -1.22594823 & -0.338685336 \\
Skewness & -0.129362158 & 0.473458164 & 0.611123298 \\
Range & 11.5 & 10 & 25 \\
Minimum & 4.5 & 5 & 5 \\
Maximum & 16 & 15 & 30 \\
Sum & 350.6 & 492.5 & 1022 \\
Count & 32 & 55 & 67 \\
Confidence Level $(95.0 \%)$ & 1.358765344 & 0.806945293 & 1.667265803 \\
\hline
\end{tabular}

Table 2. Descriptive statistics for diameter at breast height $(\mathrm{cm})$ in the study area

\begin{tabular}{llll}
\hline GIRTH $(\boldsymbol{c m})$ & PLOT A & PLOT B & PLOT C \\
\hline Mean & 22.71875 & 16.47272727 & 24.08955224 \\
Standard Error & 2.436795545 & 1.475468206 & 1.306618047 \\
Median & 17 & 13 & 22 \\
Mode & 10 & 10 & 22 \\
Standard Deviation & 13.78459724 & 10.94236508 & 10.69512965 \\
Sample Variance & 190.015121 & 119.7353535 & 114.3857983 \\
Kurtosis & -1.095678535 & 5.736276787 & 1.348262131 \\
Skewness & 0.735308419 & 2.215464388 & 0.924136991 \\
Range & 39 & 57 & 53 \\
Minimum & 9 & 6 & 7 \\
Maximum & 48 & 63 & 60 \\
Sum & 727 & 906 & 1614 \\
Count & 32 & 55 & 67 \\
Confidence Level (95.0\%) & 4.969877262 & 2.958135628 & 2.608747072 \\
\hline
\end{tabular}

\begin{tabular}{llll}
\hline \multicolumn{4}{c}{ Table 3. Descriptive statistics for Basal area $\left(\mathrm{m}^{2}\right)$ in the study area } \\
\hline Basal area $\left(\boldsymbol{m}^{2}\right)$ & PLOT A & PLOT B & PLOT C \\
Mean & 0.550021828 & 0.305488091 & 0.54433978 \\
\hline Standard Error & 0.106422421 & 0.068190771 & 0.06159297 \\
Median & 0.227795 & 0.1327495 & 0.380182 \\
Mode & 0.07855 & 0.07855 & 0.380182 \\
Standard Deviation & 0.602016122 & 0.505716296 & 0.50416022 \\
Sample Variance & 0.362423411 & 0.255748972 & 0.25417753 \\
Kurtosis & -0.632295142 & 17.94759297 & 7.1316933 \\
Skewness & 1.022299017 & 3.841995791 & 2.31361748 \\
Range & 1.7461665 & 3.0893715 & 2.7893105 \\
Minimum & 0.0636255 & 0.028278 & 0.0384895 \\
Maximum & 1.809792 & 3.1176495 & 2.8278 \\
Sum & 17.6006985 & 16.801845 & 36.470765 \\
Count & 32 & 55 & 67 \\
Confidence Level (95.0\%) & 0.217049957 & 0.136714265 & 0.12297434 \\
\hline
\end{tabular}


Table 4. The seedlings regeneration potentials after fire investigation

\begin{tabular}{llllll}
\hline & & & \multicolumn{3}{c}{ Number of seedling per plot } \\
\hline S/N & FAMILY & SPECIES & Plot A & Plot B & Plot C \\
\hline 1 & Caesalpinoideae & Afzelia Africana & 3 & 7 & 9 \\
2 & Mimosoideae & Albizia spp & 6 & 3 & 7 \\
3 & Combretaceae & Angesious leocarpus & 3 & - & 5 \\
4 & Sapotaceae & Butyrospermum paradoximum & 2 & 4 & 7 \\
5 & Compositae & Canthiun vulgare & 1 & - & - \\
6 & Caesalpinoideae & Cassia siamea & 1 & 3 & - \\
7 & Papilionoideae & Cossopteryx febrifugal & - & 4 & 6 \\
8 & Papilionoideae & Dibergia sisso & 3 & 2 & 11 \\
9 & Ebenaceae & Diospyros mispiliformis & 2 & - & 5 \\
10 & Sterculiaceae & Fagara zanthoxyloides & 7 & 3 & 3 \\
11 & Verbenaceae & Gmelina arborea & 9 & 11 & 2 \\
12 & Sterculiaceae & hildegardia barteri & 2 & 6 & 5 \\
13 & Suphorbiaceae & Magretarian sescodies & 1 & 2 & 3 \\
14 & Sapotaceae & Malacanta alniefolia & 3 & 1 & 7 \\
15 & Sapotaceae & Manikara obovata & 2 & 1 & 4 \\
16 & Mimosoideae & Parkia spp & 3 & 1 & 5 \\
17 & Meliaceae & Pseudocedrela kotschyi & 1 & - & 3 \\
18 & Anarcardiaceae & Spandia mombia & - & 3 & 5 \\
19 & Combretaceae & Terminalia glycocent & - & 2 & 3 \\
20 & Verbenacaea & Vitex doniana & 3 & 1 & 2 \\
\hline TOTAL & & $\mathbf{5 2}$ & $\mathbf{5 4}$ & $\mathbf{9 2}$ \\
\hline
\end{tabular}

Table 5. The sapling regeneration potentials after fire investigation

\begin{tabular}{llllll}
\hline S/N & FAMILY & SPECIES & Plot A & Plot B & Plot C \\
\hline 1 & Caesalpinoideae & Afzelia Africana & 2 & 4 & 3 \\
2 & Mimosoideae & Albizia spp & 1 & 6 & 7 \\
3 & Combretaceae & Angesious leocarpus & - & 3 & 6 \\
4 & Sapotaceae & Butyrospermum paradoximum & 3 & 2 & 5 \\
5 & Compositae & Canthiun vulgare & 2 & 7 & 4 \\
6 & Caesalpinoideae & Cassia siamea & 2 & 3 & 9 \\
7 & Papilionoideae & Cossopteryx felrifugal & 6 & 6 & 8 \\
8 & Papilionoideae & Dibergia sisso & 3 & 5 & 7 \\
9 & Ebenaceae & Diospyros mispiliformis & 4 & 4 & 6 \\
10 & Sterculiaceae & Fagara zanthoxyloides & - & 3 & 6 \\
11 & Verbenaceae & Gmelina arborea & 5 & 4 & 13 \\
12 & Sterculiaceae & hildegardia bateri & 2 & 1 & 3 \\
13 & Euphorbiaceae & Magretarian sescodies & 6 & - & 4 \\
14 & Sapotaceae & Malacanta alniefolia & 4 & 3 & - \\
15 & Sapotaceae & Manikara obovata & 5 & 2 & - \\
16 & Mimosoideae & Parkia spp & 3 & 1 & 2 \\
17 & Meliaceae & Pseudocedrela kotschyi & - & 1 & 2 \\
18 & Anarcardiaceae & Spandia mombia & 2 & 1 & 2 \\
19 & Combretaceae & Terminalia glycocent & 2 & 3 & 3 \\
20 & Verbenacaea & Vitex doniana & 1 & 2 & 1 \\
TOTAL & & & $\mathbf{5 3}$ & $\mathbf{6 1}$ & $\mathbf{9 1}$ \\
\hline
\end{tabular}

The regeneration potentials of the three plots were found to be noteworthy. Early and late year fire regime adopted had both positive and negative effect on the regeneration potentials of tree species. The effect of late fire burning was found to be higher than that of early year burning thus resulted into low survival on plot A than plot B. This study has established the effect and relevance of forest fire on tree species diversity and regeneration potential. The influence of different fire intensity on forest tree diversity and regeneration potential at Olokemeji forest reserve southwest Nigeria was established. Growth variables and regeneration potentials of the forest under different fire intensity was ascertained. Precise assessment and understanding of the dynamics of plant resources is important for their sustainable management, utilization and biodiversity conservation. The information on the basal area, tree height and diameter at breast and spatial distribution of trees present in a forest are efficient expression for revealing forest stand structure (Akinnagbe, 2001 and Ige, 2011). It can be seen that the highest mean height $(\mathrm{m})$ were found in plot $\mathrm{C}$ followed by plot $\mathrm{A}$ and plot $\mathrm{B}$ with mean values of 15.25 . 10.95 And 8.95 respectively. The highest mean $\mathrm{dbh}(\mathrm{cm})$ were also found in plot $\mathrm{C}$ followed by plot B and plot A respectively. The highest basal area $\left(\mathrm{m}^{2}\right)$ was found in plot $C$ followed by plot A and plot $B$ with mean values of $0.64,0.55$ and $0.30 \mathrm{~m}^{2}$ respectively. This result is an indication that dbh is a function of basal area. The girth distribution expressed the structured of forest (Sarka and Devi, 2014). 
Regeneration potential: The successful regeneration of a tree species depends on its ability to produce large number of seedlings and saplings to survive and grow (Good and Good, 1972). The forest happy good canopy cover might have affected the survival of seedlings under good canopy, probably by reducing the penetration of sunlight reaching down to the forest floor. The regenerating potentials of the three (3) plots used for this study were equally noteworthy. The highest seedlings were recorded in plot $\mathrm{C}$ with Gmelina arborea leading followed by plot B and plot A with values of 92,54 and 52 seedlings respectively.

The regenerating categories of seedlings and saplings recorded at the study site were species of high economic, social and environmental values. These species are valuable for both timber and non-timber forest products. Consequently, among the important species found are Afzelia africana, Albiza spp, Canthium Vulgare, Cassia sianea, Dibergia sisso, Gmelina arborea, parkia spp, Terminalia glycocent etc. All these are valuable species useful for social, economic and environmental benefits. Differences in regeneration behavior of various species are indicative future structure and dynamics of the forest under natural conditions. The fire treatment on the other hand has both positive and negative benefits on the forest ecosystems Schimmel and Granstrom (1996). Modes of regeneration not only determine survival through a disturbance but also influence growth and survival following disturbance, but. Sprouts may form larger, taller crowns more rapidly that seedlings (Miller and Kauffman, 1998). Also fire intensity on forest trees allow the new flush of species and aids dispersal and species diversity (McDaniel, 2000).

Conclusion: The effect of late fire burning was found to be higher than that of early year burning thus resulted into low survival on plot $\mathrm{A}$ than plot $\mathrm{B}$. The study established that different fire regime adopted aids regeneration of seedlings and saplings at the study area. Natural regeneration is a central component for tropical forest ecosystem dynamics and is essential for preservation and maintenance of biodiversity. Prescribed or controlled burning is appropriate sivicultural management tool for stimulating basal area growth, natural regeneration, production of tree species Seedlings and saplings.

\section{REFERENCES}

Adegbola, PO (1983). Fuel Appraisal/Evaluation for Fire Control and Uses. Voluntary Paper presented at the workshop on forest fires: J. Ecol and Environ. Forestry Research Inst. of Nig. (F.R.I.N.) Ibadan. 10-12 ${ }^{\text {th }}$ October 1983.
Akinnagbe, A (2001). Stem diameter distribution model in Akure forest reserve, Nigeria. M.Tech Thesis submitted to the Department of Forestry and Wood Technology, Federal University of Technology, Akure.

Aubreville, A (1949). Climate, Forest Desertification de 1' Afrique Tropicale, Paris. Conservation, Forests and Lands (Publ.)

Good, NF; Good RE (1972). Population dynamics of tree seedlings and saplings in mature eastern hardwood forests. Bulletin of the Torrey Botanical Club 99: 172-178.

Ige, PO (2011). Stem Diameter Distribution Models for a Natural Stand in Shasha Forest Reserve, Nigeria. M.Sc Thesis submitted to the Department of Forest Resources Management, University of Ibadan, Nigeria. pp 75-86.

Keay, RWJ (1953). An Outline of Nigeria Vegetation. Ed. 2. Government Printer, Lagos.

Khan ML; Rai, JPN; Tripathi, RS (1987). Population structure of some tree species in disturbed and protected sub-tropical forests of north-east India. Acta Oecologica-Oecologia Applicata 8: 247255.

Khumbongmayum AD; Khan ML; Tripathi, RS (2006). Biodiversity conservation in sacred groves of Manipur, northeast India: population structure and regeneration status of woody species. J. Biodiv. Con. 15: 2439-2456.

Luke, RH; McArthur, AG (1978). Bush fires in Australia. Department of Primary Industry, Forestry and Timber Bureau. CSIRO Division of Forestry Research.

McDaniel, JM (2000). Politics of ethnicity. Ph.D. Thesis. University of Florida, Gainesville, FL, 230 pp.

Meli, P (2003). Restauración ecoló gica de bosques tropicales. Veinte an os de investigacio'n acade'mica. Interciencia 28:581-589.

Miller, PM; Kauffman, J.B (1998b). Seedling and sprout response to slash and burn agriculture in a tropical deciduous forest. Biotropica 30, 538546.

Murphy, PG; Lugo, AE (1986). Ecology of tropical dry forest. Annual Review of Ecology and 
Systematics 17:67-88. Nigeria First Biodiversity Report (2001). Available at: $\quad$ www.cbd.int/doc/world/ng/ng-nrol"nigeriafirstbiodiversityreport2001.

Oloketuyi, AJ; Ibimilua WF; Akinyemi, OD; Oyelowo, OJ; Olatidoye, OR. (2020). Effects of forest fire on tree species diversity in olokemeji Forest Reserve. Australian J. of Sci. and Tech. Vol 4(3). 319-325

Sanchez-Azofeifa, GA; Kalacska, M; Quesada, JC; Calvo-Alvarado, JM; Nassar, JP; Rodri'guez. (2005). Need for integrated research for a sustainable future in tropical dry forests. Conser. Bio. 19:285-286.

Sarkar; Devi (2014). 1(2): Tree diversity and population structure in undisturbed and humanimpacted stands of tropical wet evergreen forest in Arunachal Pradesh, Eastern Himalayas, India. Biodiv. Conser. 12: 1753-1773
Schimmel, J; Granstrom, A (1996). Fire severity and vegetation response in the boreal Swedish forest. Ecol. 77, 1450-1496.

Simpfendorfer, KJ (1989). Trees, Farms and Fires. Lands and Forests Bulletin No. 30.

Sukhdev, P (2010). The Economics of Biodiversity and Ecosystem Services of Tropical Forests. Tropical Forest Update 20(1): 8-10.

Udugba, IA (1997). The Effects of Forest Fires on the growth of a Tropical Low-Land Rainforest. M.Sc Thesis submitted to the faculty of Forestry and Ecology, University of Gottigen, Germany. 